\title{
THE RISKS AND WEAKNESSES OF THE INTERNATIONAL CRIMINAL COURT FROM AMERICA'S PERSPECTIVE
}

\author{
JOHN R. BOLTON*
}

In the aftermaths of both World War I and World War II, the United States engaged in significant domestic political debates over its proper place in the world. President Wilson's brainchild, the League of Nations, was the centerpiece of the first debate, and the United Nations the centerpiece of the second. The conventional wisdom is that the dark forces of isolationism defeated Wilson's League in the Senate, and that the advent of the Cold War gridlocked the nascent United Nations, preventing it from assuming the role intended for it in preserving international peace and security. While the mythology surrounding both of these important debates is wrong and incoherent in many respects, ${ }^{1}$ there is no doubt of the far-reaching implications of American political decisions attendant on them.

Neither the debate over the League nor the one over the United Nations settled the issue of America's proper relationship with other governments and international organizations. During the Cold War, there was little or no occasion for the debate to re-emerge in the United States because the life-or-death struggle with Communism dominated U.S. attention, at least at the national level. Nonetheless, below the surface, largely in academic circles, those debates favoring international legal measures to constrain the independence of nation states continued their efforts, both here and in Europe. Although motivated by a wide range of considerations, many of which were contradictory, one broad theme was that it was the nation state itself, and the seemingly inescapable at-

Copyright (C) 2001 by John R. Bolton

This article is also available at http://www.law.duke.edu/journals/64LCPBolton.

* Senior Vice President, American Enterprise Institute; Assistant Secretary of State for International Organization Affairs, Bush Administration.

A substantially similar version of this article appeared in 41 VIRGINIA J. INT'L L. 186 (2000).

1. While there is no real opportunity here to discuss at length the subject of "American isolationism," it is in fact a very unsatisfactory historical template for evaluating U.S. foreign policy. "Isolationism" as a characterization is conclusory and derogatory and, therefore, for those who wield it, needs little supportive evidence or argument. Indeed, for those most disturbed by it, "isolationism" is much like Justice Potter Stewart's famous definition of "hard-core pornography": "I know it when I see it." See Jacobellis v. Ohio, 378 U.S. 184, 197 (1964) (Stewart, J., concurring).

Unfortunately, for analytical purposes at least, the opposing term "internationalism" itself obscures more than it illuminates. Those interested in pursuing the point may wish to see my essay Unilateralism Is Not Isolationism, in UNDERSTANDING THE UNILATERALISM IN AMERICAN FOREIGN RELATIONS 50-82 (Gwyn Prins ed., 2000). A complementary but somewhat different and more extensive historical analysis of American foreign policy is found in WALTER A. MCDOUGALL, PROMISED LAND, CRUSADER STATE (1997). 
tendant concept of "balance of power," that posed the most important threat to a regime of international peace. ${ }^{2}$ Accordingly, many looked for ways to constrain nation states, to limit their ability to act unilaterally, especially in the use of military force. It was hoped that such constraints would lead generally to reduced international tensions and the consequent temptation to use force in resolving disputes among nations. ${ }^{3}$

America's victory in the Cold War seemingly freed the United States from many of the constraints that had kept the broader debate about America's place in the world underground. Especially with the 1992 election of President Clinton, the first President since Harry S. Truman who actually seemed to have faith in the United Nations, the debate turned on again. Explicitly espousing a foreign policy of "assertive multilateralism," President Clinton launched an ambitious experiment in a U.N.-led "nation building" in Somalia. The experiment collapsed with the deaths of eighteen Americans in Mogadishu in late 1993, and the vocabulary of "assertive multilateralism" largely disappeared. ${ }^{4}$

Nonetheless, although the rhetoric stopped, the underlying policy did not, revealing itself in a multitude of policy initiatives. The Clinton Administration engineered a series of international agreements, such as the Kyoto Protocol, ${ }^{5}$ the Landmines Convention, ${ }^{6}$ the Convention on Biological Diversity, ${ }^{7}$ and many others, some of which it signed and some of which it did not for fear of certain defeat in the U.S. Senate. This penchant for multilateral solutions also reflected an enduring if often badly mistaken legalism that has permeated American foreign policy during the twentieth century.

Nowhere was this convergence of multilateral and legalistic thought more evident than in the Clinton Administration's pursuit of a permanent International Criminal Court ("ICC"). ${ }^{8}$ In the eyes of its supporters, the ICC is simply an overdue addition to the family of international organizations, an evolution-

2. See, e.g., Our Global Neighborhood: The Report of the COMmission on Global GOVERNANCE 78-80 (1995).

3. An excellent examination of the integrationist theory, from a British perspective, is HUGO Young, ThIS Blessed Plot: BRITAIN AND EUROPE FROM CHURCHILl TO BLAIR (1998). For the best one-volume historical and analytical discussion of the "balance of power" concept, see HENRY KISSINGER, DIPLOMACY (1994).

4. I have examined the Somalia debacle in more detail in Wrong Turn in Somalia, 73 FOREIGN AfF. 56 (1994), and Somalia and the Problems of Doing Good: A Perspective From the State Department, in Close Calls: InTERVEnTION, Terrorism, Missile DeFEnSE AND "Just WAR" TODAY 145 (Elliott Abrams ed., 1998).

5. The agreement, signed in Kyoto, Japan, on December 10, 1997, is a Protocol to the United Nations Framework Convention on Climate Change. See 37 I.L.M. 22.

6. 36 I.L.M. 1507 (Nov. 1997).

7. June 5, 1992, 31 I.L.M. 818 (entered into force Dec. 19, 1993).

8. The Administration's chief negotiator on the ICC, David J. Scheffer, wrote explicitly that "[t]he ultimate weapon of international judicial intervention would be a permanent international criminal court.” International Judicial Intervention, 102 FOREIGN POL'Y 34, 48 (Spring 1996). Indeed, one of the first acts of the new Administration's foreign policy was to support the adoption of Security Council Resolution 808, creating an international war crimes tribunal for Yugoslavia, on February 22, 1993. The Rwanda tribunal followed in Security Council Resolution 935 in July 1994. 
ary step following the Nuremberg tribunal, and a logical institutional development over the ad hoc war crimes courts in Bosnia and Rwanda.

So described, one might assume that the ICC fits logically into history's orderly march toward the peaceful settlement of international disputes, sought since time immemorial. ${ }^{9}$ But the real (if usually unstated, and far distant) objectives of the ICC's supporters are to assert the supremacy of its authority over nation states, and to promote prosecution over alternative methods for dealing with the worst criminal offenses, whether occurring in war or through arbitrary domestic power. This is but one of many reasons why the Statute of Rome ${ }^{10}$ is harmful to the national interests of the United States, is unsound foreign policy, and is a threat to the independence and flexibility that America's military forces need to defend U.S. national interests around the world.

In fact, the court and the prosecutor are illegitimate. The ICC's principal failing is that its components do not fit into a coherent "constitutional" design that delineates clearly how laws are made, adjudicated, and enforced, subject to popular accountability and structured to protect liberty. Instead, the court and the prosecutor are simply "out there" in the international system. This approach is clearly inconsistent with American standards of constitutional order, and is, in fact, a stealth approach to erode our constitutionalism. That is why this issue is, first and foremost, a liberty question.

The ICC's failing stems from its purported authority to operate outside (and on a plane superior to) the U.S. Constitution, and thereby to inhibit the full constitutional autonomy of all three branches of the U.S. government, and, indeed, of all states party to the statute. ${ }^{11}$ ICC advocates rarely assert publicly that this result is central to their stated goals, but it must be for the court and prosecutor to be completely effective. And it is precisely for this reason that, strong or weak in its actual operations, the ICC has unacceptable consequences for the United States.

The court's illegitimacy is basically two-fold: substantive and structural. As to the former, the ICC's authority is vague and excessively elastic. This is most emphatically not a court of limited jurisdiction. Even for genocide, the oldest codified among the three crimes specified in the Rome Statute, ${ }^{12}$ there is hardly complete clarity on its meaning. The ICC demonstrates graphically all of the inadequacies of how "international law" is created.

The U.S. Senate, for example, cannot accept the statute's definition of genocide unless it is prepared to reverse the position it took in February 1986 in ap-

9. Secretary-General Says Establishment of International Criminal Court Is Major Step in March Towards Universal Human Rights, Rule of Law, United Nations Press Release L/ROM/23 (1988).

10. The text of the Rome Statute of the International Criminal Court ("the Rome Statute") is found in U.N. DOC. A/CONF.183/9 (1998).

11. There is no doubt that such an effort fails under long-accepted standards of American Constitutional law. See, e.g., Reid v. Covert, 354 U.S. 1 (1957). There, Justice Black's plurality opinion stated unambiguously that the "Court has regularly and uniformly recognized the supremacy of the Constitution over a treaty." Id. at 17.

12. Rome Statute, supra note 10, art. 6. 
proving the Genocide Convention of 1948, when it attached two reservations, five understandings, and one declaration. ${ }^{13}$ By contrast, Article 120 of the Rome Statute provides explicitly and without any exceptions that "[n]o reservations may be made to this [s]tatute." Thus confronted with the statute's definition of "genocide" that ignores existing American reservations to the underlying Genocide Convention, the Senate would not have the option of attaching these reservations (or others) to any possible ratification of the statute. Stripped of the reservation power, the United States would risk expansive and mischievous definitional interpretations by a politically motivated court. Indeed, the "no reservations" clause appears obviously directed against the United States and its protective Senate, and is a treaty provision we should never agree to.

The Rome Statute's two other offenses, crimes against humanity and war crimes,$^{14}$ are even vaguer, as is the real risk that an activist court and prosecutor can broaden the language of the terms essentially without limit. ${ }^{15}$ It is precisely this risk that has led our Supreme Court to invalidate state and federal criminal statutes that fail to give adequate notice of exactly what they prohibit under the "void for vagueness" doctrine. Unfortunately, "void for vagueness" is largely an American shield for civil liberties.

A fair reading of the treaty, for example, leaves the objective observer unable to answer with confidence whether the United States was guilty of war crimes for its aerial bombing campaigns over Germany and Japan in World War II. Indeed, if anything, a straightforward reading of the language probably indicates that the court would find the United States guilty. A fortiori, these provisions seem to imply that the United States would have been guilty of a war crime for dropping atomic bombs on Hiroshima and Nagasaki. ${ }^{16}$ This is intolerable and unacceptable.

The list of ambiguities goes on and on. How will these vague phrases be interpreted? Who will advise a President that he is unequivocally safe from the retroactive imposition of criminal liability if he guesses wrong? Is even the defensive use of nuclear weapons a criminal violation?

We are nowhere near the end of the list of prospective "crimes" that can be added to the statute. Many were suggested at Rome and commanded wide support from participating nations. The most popular was the crime of "aggression," which was included in the statute but not defined. ${ }^{17}$ Although frequently easy to identify, "aggression" can at times be something in the eye of the beholder. Thus, Israel justifiably feared in Rome that its preemptive strike in the Six-Day War almost certainly would have provoked a proceeding against top

13. The reservations, understandings and declaration are reprinted in 28 I.L.M. 782 (1989).

14. Rome Statute, supra note 10, arts. 7, 8 .

15. Id. arts. 7, 8.2(b)(1)(iv).

16. Some governments and NGOs proposed in Rome that the use of nuclear weapons be specifically prohibited. While these proposals were not accepted, the statute's actual language can certainly support arguments about the "criminal" effects of nuclear weapons for those seeking to outlaw them.

17. Rome Statute, supra note 10, arts. 5.1(d), 5.2. 
Israeli officials. Moreover, there is no doubt that Israel will be the target of a complaint concerning conditions and practices by the Israeli military in the West Bank and Gaza. The United States, with continuous bipartisan support for many years, has attempted to minimize the disruptive role that the United Nations has all too often played in the Middle East peace process. We do not now need the ICC interjecting itself into extremely delicate matters at inappropriate times. Israel, therefore, was one of the few governments that voted with the United States against the statute.

But even beyond this risk is the larger agenda of many ICC supporters, of the nearly endless articulation of "international law" that continues ineluctably and inexorably to reduce the international discretion and flexibility of nation states, and the United States in particular. In judging the Rome Statute, we should not be misled by examining simply the substantive crimes contained in the final document. We have been put on very clear notice that this list is illustrative only, and just the start. ${ }^{18}$

The fundamental problem with the latitude of the ICC's interpretive authority stems from the decentralized and unaccountable way in which "international law," and particularly customary international law, is made. ${ }^{19}$ It is one of those international law phenomena that just happens "out there," among academics and activists. While the historical understanding of customary international law was that it evolved from the practices of nation states over long years of development, today we have theorists who speak approvingly of "spontaneous customary international law" that the cognoscenti discover almost overnight. This is simply not acceptable to any free person.

The idea that nations and individuals can be bound through "international law" has a surface appeal precisely because it sounds so familiar and comfortable to citizens of countries such as ours, where we actually do live by the "rule of law." In reality, however, this logic is naive, abstract to the point of irrelevance from real international relations, and in many instances simply dangerous. It mistakes the language of law for the underlying concepts and structures that actually permit legal systems to function, and it seriously misapprehends what "law" can realistically do in the international system. ${ }^{20}$

In fact, what happens in "international law," especially in "customary international law," meets none of the tests of what we understand "law" to be. In

18. Article 10 of the Rome Statute states explicitly that nothing in the substantive jurisdictional provisions "shall be interpreted as limiting or prejudicing in any way existing or developing rules of international law for purposes other than this [s]tatute."

19. Japan's Permanent U.N. Representative, serving as the head of Japan's delegation to the Rome Conference, said approvingly that "[t]he war crimes which are considered to have become part of customary international law should also be included, while crimes which cannot be considered as having crystallized into part of customary international law should be outside the scope of the Court." See Statement of Ambassador Hisashi Owada, June 15, 1998, at $2<\mathrm{http} / /$ www.un.org/icc/speeches/ 615jpn.htm>.

20. For an extended-and completely unintentional-display of most of the errors of this approach, see generally THE COMMISSION ON GLOBAL GOVERNANCE, OUR GLOBAL NEIGHBORHOOD (1995). 
common-sense terms, "law" is a system of rules that regulates relations among individuals and associations, and between them, and sources of legitimate coercive authority, that can enforce the rules. The source of coercive authority is legitimate to the extent it rests on popular sovereignty. Any other definition is either incoherent, or unacceptable to anyone who values liberty.

To have real "law" in a free society, there must be a framework-a constitution-that defines government authority and thus limits it, preventing arbitrary power. As the great scholar C. H. McIlwain wrote, "[a]ll constitutional government is by definition limited government." ${ }^{21}$ There must also be political accountability, as demonstrated through reasonably democratic popular controls over the creation, interpretation, and enforcement of the laws. These prerequisites must be present to have agreement on three key structures: authoritative and identifiable sources of the law for resolving conflicts and disputes among parties; methods and procedures for declaring and changing the law; and the mechanisms of law interpretation, enforcement, execution, and compliance.

In "international law," essentially none of this exists. There is no process tying international authority to the political consent of the global population, for true democratic legitimization. There is no definitive dispute-resolution mechanism, and no agreed-upon enforcement, execution, or compliance mechanisms. No international organization that exists today honestly meets any acceptable test for accountable law-giving, law-interpreting, or lawenforcing institutions.

Particularly important for Americans, of course, is how all of this applies to us. Proponents of international governance see the United States as the chief threat to the "new world order" they are trying to create. Small villains who commit heinous crimes can kill individuals and even entire populations, but only the United States can neutralize or actually thwart the "new world order" itself. Under our Constitution, any Congress may, by law, amend an earlier act of Congress, including treaties, thus freeing the United States unilaterally of any obligation. The Supreme Court made this point explicitly in the Chae Chan Ping case:

A treaty ... is in its nature a contract between nations, and is often merely promissory in its character, requiring legislation to carry its stipulations into effect. Such legislation will be open to future repeal or amendment. If the treaty operates by its own force ..., it can be deemed in that particular only the equivalent of a legislative act, to be repealed or modified at the pleasure of Congress. In either case the last expression of the sovereign will must control. ${ }^{22}$

If treaties cannot legally "bind" the United States, it need not detain us long to dismiss the notion that "customary international law" has any binding legal effect either. The idea that the amorphous concept of what is "customary" can bind the world's nation states seems to assume tacitly that the Global Constitu-

21. Charles Howard Mcilwain, Constitutionalism: ANCIENT AND MOdERn 23 (1958).

22. Chae Chan Ping v. United States, 130 U.S. 581, 600 (1889). 
tion contains a Global Supremacy Clause. But this is simply an exercise of false advertising.

Moreover, we must also understand some facts of international political life. If the American citadel can be breached, advocates of binding international law will be well on the way toward the ultimate elimination of the "nation state." Thus, it is important to understand why America and its Constitution would have to change fundamentally and irrevocably if we accepted the ICC. This constitutional issue is not simply a narrow, technical point of law, certainly not for the United States, where the overwhelming popular and political consensus supports the superior status of the Constitution over the claims of international law. Those who disagree must explain to the people of America how the world's strongest and most free representative democracy, simply by adhering to its own Constitution, somehow contravenes international law.

As troubling as the ICC's substantive and jurisdictional problems are, the problems raised by the statute's main structures-the court and the prosecutor-are still worse. Particularly important here is the independent prosecutor, who is responsible for conducting investigations and prosecutions before the court. The prosecutor may initiate investigations based on referrals by states' parties to the statute, or on the basis of information which he or she otherwise obtains. ${ }^{23}$ While the Security Council may refer matters to the ICC, or order it to cease a pending investigation, the Council is essentially barred from any real role in the ICC's work. ${ }^{24}$

What is at issue in the prosecutor is the power of law enforcement, a powerful and necessary element of executive power. Never before has the United States been asked to place any of that power outside the complete control of our national government. Our main concern should not be that the prosecutor will target for indictment the isolated U.S. soldier who violates our own laws and values, and his or her military training and doctrine, by allegedly committing a war crime. Instead, our main concern should be for our country's top civilian and military leaders, those responsible for our defense and foreign policy. They are the real potential targets of the ICC's politically unaccountable prosecutor.

Unfortunately, the United States has had considerable experience in the past two decades with "independent counsels," and that depressing history argues overwhelmingly against international repetition. Simply launching massive criminal investigations has an enormous political impact. Although subsequent indictments and convictions are unquestionably more serious, a zealous independent prosecutor can make dramatic news simply by calling witnesses and gathering documents, without ever bringing formal charges.

Indeed, the supposed "independence" of the prosecutor and the court from "political" pressures (such as the Security Council) is more a source of concern

23. See Rome Statute, supra note 10, arts. 13(a), 13(c), 14.

24. See id. arts. 13(b), 16. 
than an element of protection. "Independent" bodies in the United Nations system have often demonstrated themselves to be more highly politicized than some of the explicitly political organs. ${ }^{25}$ True political accountability, by contrast, is almost totally absent from the ICC, which lacks both any semblance of democratic accountability or effective governmental oversight and control. If anything, "public choice" analysis tells us that the ICC will be "captured" not by governments but by NGOs and others with narrow special interests, and the time and resources to pursue them.

The American concept of separation of powers, imperfect though it is, reflects the settled belief that liberty is best protected when, to the maximum extent possible, the various authorities legitimately exercised by government are placed in separate branches. So structuring the national government, the framers of the Constitution believed, would prevent the excessive accumulation of power in a limited number of hands, thus providing the greatest protection for individual liberty. Continental European constitutional structures do not, by and large, reflect a similar set of beliefs. They do not so thoroughly separate judicial from executive powers, just as their parliamentary systems do not so thoroughly separate executive from legislative powers. That, of course, is entirely their prerogative, and substantially explains why they appear to be more comfortable with the ICC's structure, which closely melds prosecutorial and judicial functions in the European fashion. They may be able to support such an approach, but we should not.

In addition, the Constitution provides that the discharge of executive authority will be rendered accountable to the citizenry in two ways. First, the law-enforcement power is exercised only through an elected President. The President is constitutionally charged with the responsibility to "take Care that the Laws be faithfully executed," ${ }^{26}$ and the constitutional authority of the actual law-enforcers stems directly from the only elected executive official. Second, Congress, all of whose members are popularly elected, both through its statutemaking authority and through the appropriations process, exercises significant influence and oversight. When necessary, the congressional impeachment power serves as the ultimate safeguard.

In European parliamentary systems, these sorts of political checks are either greatly attenuated or entirely absent, just as with the ICC's central structures, the court and prosecutor. They are accountable to no one. The prosecutor will answer to no superior executive power, elected or unelected. Nor is there any legislature anywhere in sight, elected or unelected, in the Rome Statute. The prosecutor, and his or her as yet uncreated investigating, arresting, and detaining apparatus, is answerable only to the court, and then only partially. The Europeans may be comfortable with such a system, but that is one reason why they are Europeans and we are not.

25. UNESCO and the ILO, both of which the United States has withdrawn from (although later remaining within the ILO), are two examples of "specialized agencies" that became hightly politicized.

26. U.S. CONST. art. II. 
By longstanding American principles, the ICC's structure completely fails to provide sufficient accountability to warrant vesting the prosecutor with the statute's enormous power of law enforcement. Political accountability is utterly different from "politicization," which all can agree should form no part of the decisions of either the prosecutor or the court. Today, however, precisely contrary to the proper alignment, the ICC has almost no political accountability, and carries an enormous risk of politicization. This analysis underscores that our main concern is not the isolated prosecutions of individual American military personnel around the world. It has everything to do with the fundamental American fear of unchecked, unaccountable power.

Beyond the particular American interests adversely affected by the ICC, are the ICC's more general deficiencies that will affect all nations. Thus, although the gravest danger from the American perspective is that the ICC will be overbearing and unaccountable, an at-least-equally-likely possibility is that, in the world at large, the new institution will be powerless and ineffectual. While this analysis may sound superficially contradictory, the ICC is ironically one of those rare creations that may be simultaneously dangerous and weak because its intellectual underpinnings are so erroneous or inadequate in so many respects.

The most basic error is the belief that the ICC will have a substantial, indeed decisive, deterrent effect against the possible perpetration of heinous crimes against humanity. Rarely if ever, however, has so sweeping a proposal had so little empirical evidence to support it. The evidence demonstrates instead that the court and the prosecutor will not achieve their central goal because they do not, cannot, and should not have sufficient authority in the real world.

Behind their optimistic rhetoric, ICC proponents have not a shred of evidence supporting their deterrence theories. In fact, they fundamentally confuse the appropriate roles of political and economic power, diplomatic efforts, military force, and legal procedures. No one seriously disputes that the barbarous actions about which ICC supporters complain are unacceptable, but they make a fundamental error in trying to transform international matters of power and force into matters of law. Misunderstanding the appropriate roles of force, diplomacy, and power in the world is not just bad analysis, but bad and potentially dangerous policy.

Recent history is filled with cases where even strong military force or the threat of force failed to deter aggression or the commission of gross abuses of human rights. ${ }^{27}$ ICC proponents concede as much when they cite cases where the "world community" has failed to pay adequate attention, or failed to intervene in a sufficiently timely fashion to prevent genocide or other crimes against

27. Both supporters and critics of contemporary deterrence theory contemplate a far more complex politico-military environment than the simplistic world of ICC advocates. See, e.g., THOMAS C. Schelling, The Strategy of Conflict 6-20 (1960); Thomas C. Schelling, ARms And INFLUENCE 35-91 (1966); compare KARL W. DEUTSCH, THE ANALYSIS OF INTERNATIONAL Relations 124-30 (1968) and Charles J. Hitch \& Roland N. MCKeAn, The ECONOMics of DEFENSE IN THE NuCLEAR AGE 350-57 (1960). 
humanity. The new court and prosecutor, it is said, will now guarantee against similar failures.

But this is surely fanciful. Deterrence ultimately depends on perceived effectiveness, and the ICC fails badly on that point. Even if administratively competent, the ICC's authority is far too attenuated to make the slightest bit of difference either to the war criminals or to the outside world. In cases where the West in particular has been unwilling to intervene militarily to prevent crimes against humanity as they were happening, why will a potential perpetrator feel deterred by the mere possibility of future legal action? A weak and distant court will have no deterrent effect on the hard men like Pol Pot most likely to commit crimes against humanity. Why should anyone imagine that bewigged judges in The Hague will succeed where cold steel has failed? Holding out the prospect of ICC deterrence to the truly weak and vulnerable is simply a cruel joke.

Beyond the predictive issue of deterrence, it is by no means clear that "justice" is everywhere and always consistent with the attainable political resolution of serious political and military disputes, whether between or within states. It may be, or it may not be. Human conflict teaches that, unfortunately for moralists and legal theorists, mortal policymakers often must make tradeoffs among inconsistent objectives. This can be a painful and unpleasant realization, confronting us as it does with the irritating facts of human complexity, contradiction, and imperfection. Some choose to ignore these troubling intrusions of reality, but an American President does not have that luxury.

The existing international record of adjudication is not encouraging. Few Americans argue that the International Court of Justice ("ICJ") ${ }^{28}$ has garnered the legitimacy sought by its founders in 1945. This is more than ironic, because much of what was said then about the ICJ anticipates recent claims by ICC supporters. $^{29}$ These touching sentiments were not borne out in practice for the ICJ, which has been largely ineffective when invoked and more often ignored in significant international disputes. Indeed, the United States withdrew from the mandatory jurisdiction of the ICJ after its erroneous Nicaragua decisions, and it has even lower public legitimacy here than the rest of the United Nations. ${ }^{30}$

Among the several reasons why the ICJ is held in such low repute, and what is candidly admitted privately in international circles, is the highly politicized nature of its decisions. Although ICJ judges supposedly function independently of their governments, their election by the United Nation's General Assembly is a highly politicized matter, involving horse trading among and within the United Nation's several political groupings. Once elected, ICJ judges typically

28. Statute of the International Court of Justice, 59 Stat. 1055, TS No. 993 ("ICJ Statute").

29. The ICJ at least fits more conventionally into traditional notions of "international law" than the ICC, because the ICJ has jurisdiction only over disputes between states, not over individual guilt or innocence for violations of international codes of conduct. See ICJ Statute art. 34(1). The ICJ can also render advisory opinions to the United Nations. See U.N. Charter art. 96 (1945).

30. The Nicaragua decisions are discussed at length in Robert Bork, The Limits of International Law, 18 NAT'L INTEREST 3 (Winter 1989-90). 
vote along highly predictable national lines except in the most innocuous of cases. We do not need a repetition of that hypocrisy.

Although supposedly a protection for the ICC's independence, the provisions for the "automatic jurisdiction" of the court and the prosecutor are unacceptably broad. They constitute a clear break from the basic premise of the ICJ that there is no jurisdiction without the consent of the state parties. ${ }^{31}$ Because parties to the ICC may refer alleged crimes to the prosecutor, we can virtually guarantee that some will, from the very outset, seek to use the court for political purposes.

Another significant failing is that the Rome Statute substantially minimized the Security Council's role in ICC affairs. In requiring an affirmative Council vote to stop a case, the statute shifts the balance of authority from the Council to the ICC..$^{32}$ Moreover, a veto by a permanent member of such a restraining Council resolution leaves the ICC completely unsupervised. This attempted marginalization of the Security Council is a fundamental new problem created by the ICC that will have a tangible and highly detrimental impact on the conduct of U.S. foreign policy. The Council now risks having the ICC interfere in its ongoing work, with all of the attendant confusion between the appropriate roles of law, politics, and power in settling international disputes. It seriously undercuts the role of the five permanent members of the Council, and radically dilutes their veto power.

More broadly, accumulated experience strongly favors a case-by-case approach, politically and legally, rather than the inevitable resort to adjudication contemplated by the ICC. Circumstances differ, and circumstances matter. Atrocities, whether in international wars or in domestic contexts, are by definition uniquely horrible in their own times and places. ${ }^{33}$

For precisely that reason, so too are their resolutions unique. When the time arrives to consider the crimes, that time usually coincides with events of enormous social and political significance: negotiation of a peace treaty, restoration of a "legitimate" political regime, or a similar milestone. In such momentous circumstances, there are typically issues beyond administering justice to those who committed heinous crimes during the preceding turbulence. Many questions are clearly political, not legal: How shall the formerly warring parties live with each other in the future? What efforts shall be taken to expunge the causes of the previous inhumanity? Can the truth of what actually happened be established so that succeeding generations do not make the same mistakes?

One alternative to the ICC is South Africa's Truth and Reconciliation Commission. ${ }^{34}$ In the aftermath of apartheid, the new government faced the dif-

31. Although "automatic jurisdiction" is not expressly stated in the Rome Statute, it follows from Article 12. See Alan Baker, The International Criminal Court: Israel's Unique Dilemma, 18 JUsTICE, 18, 22 (Autumn 1998).

32. See Rome Statute, supra note 10, art. 16.

33. A recent discussion of these complexities may be found in MARTHA MinOw, BETWEEN VENGEANCE AND FORGIVENESS: FACING HISTORY AFTER GENOCIDE AND MASS VIOLENCE (1998).

34. See id. ch. 4. 
ficult task of establishing and legitimizing truly democratic governmental institutions while dealing simultaneously with earlier crimes. One option was widespread prosecutions against the perpetrators of human rights abuses, but the new government chose a different model. Under the Commission's charter, the alleged offenders came before it and confessed past misdeeds. Assuming they confessed truthfully, the Commission in effect pardoned them from prosecution. This approach was intended to make public more of the truth of the apartheid regime in the most credible fashion, to elicit thereby admissions of guilt, and then to permit society to move ahead without the continued opening of old wounds that trials, appeals, and endless recriminations might bring.

One need not argue that the South African approach should be followed everywhere, or even necessarily that it was correct for South Africa. But it is certainly fair to conclude that that approach is radically different from the ICC, which like most criminal law-enforcement institutions seeks vindication, punishment, and retribution as its goals.

It may be that, in some disputes, neither retribution nor complete truthtelling is the desired outcome. In many former Communist countries, for example, citizens are still wrestling with the handling of secret police activities of the now-defunct regimes. So extensive was the informing, spying, and compromising in some societies that a tacit decision was made that the complete opening of secret police and Communist Party files will either not occur, or will happen with exquisite slowness over a very long period. In effect, these societies have chosen "amnesia" because it is simply too difficult for them to sort out relative degrees of past wrongs, and because of their desire to move ahead.

One need not agree with these decisions to have at least some respect for the complexity of the moral and political problems they address. Only those completely certain of their own moral standing and utterly confident in their ability to judge the conduct of others in difficult circumstances can reject the amnesia alternative out of hand. Our experience should counsel for a prudent approach that does not invariably insist on international adjudication even over a course that the parties to a dispute might themselves agree upon. Indeed, with a permanent ICC, one can predict that one or more disputants might well invoke its jurisdiction at a selfishly opportune moment, and thus, ironically, make an ultimate settlement of their dispute more complicated or less likely.

Another alternative, of course, is for the parties themselves to try their own alleged war criminals. Indeed, there are substantial arguments that the fullest cathartic impact of the prosecutorial approach to war crimes and similar outrages occurs when the responsible population itself comes to grips with its past and administers appropriate justice. ICC advocates usually disregard this possibility, either because it is inconvenient to their objectives, or because it utilizes national judicial systems and agreements among (or within) nation states to implement effectively. They pay lip service to the doctrine of "complementarity," or deference to national judicial systems, but like so much else connected with the ICC, complementarity is simply an assertion, utterly unproven and un- 
tested. $^{35}$ In fact, if complementarity has any real substance, it argued against creating the ICC in the first place, or, at most, creating ad hoc international tribunals. Indeed, it is precisely the judicial systems that the ICC would likely supplant where the international effort should be to encourage the warring parties to resolve questions of criminality as part of a comprehensive solution to their disagreements. Removing key elements of the dispute, especially the emotional and contentious issues of war crimes and crimes against humanity, undercuts the very progress that these peoples, victims and perpetrators alike, must make if they are ever to live peacefully together.

Take Cambodia. Although the Khmer Rouge genocide is frequently offered as an example of why the ICC is needed, its proponents never explain why the Cambodians should not themselves try and adjudicate alleged war crimes. To create an international tribunal for the task implies the incurable immaturity of Cambodians and paternalism by the international community. Repeated interventions, even benign ones, by global powers is no substitute for the Cambodians coming to terms with themselves. ${ }^{36}$

ICC proponents frequently assert that the histories of the Bosnia and Rwanda tribunals established by the Security Council demonstrate why a permanent ICC is necessary. ${ }^{37}$ The limited and highly unsatisfactory experience with ad hoc tribunals proves precisely the contrary. Bosnia is a clear example of how a decision to detach war crimes from the underlying political reality advances neither the political resolution of a crisis nor the goal of punishing war criminals. $^{38}$ ICC proponents complain about the lack of NATO resolve in apprehending alleged war criminals. But if not in Bosnia, where? If the political will to risk the lives of troops to apprehend indicted war criminals there did not exist, where will it suddenly spring to life on behalf of the ICC?

It is by no means clear that even the tribunal's "success" would complement or advance the political goals of a free and independent Bosnia, the expiation of war-time hostilities, or reconciliation among the Bosnian factions. In Bosnia, there are no clear communal winners or losers. Indeed, in many respects, the war in Bosnia is no more over than it is in the rest of former Yugoslavia. Thus, there is no agreement, either among the Bosnian factions or among the external intervening powers, about how the war crimes tribunal fits into the overall political dispute or its potential resolution. There is no serious discussion about Bosnia conducting its own war crimes trials. Bosnia shows that insisting on le-

35. Rome Statute, supra note 10, arts. 1, 17.

36. See generally ElizABETH BECKer, WHEN THE WAR WAS OVER: CAMBOdiA AND THE KHMER Rouge REVOLUTION (1998).

37. See Scheffer, supra note 8; see also Michael P. Scharf, The ICC's Jurisdiction over the Nationals of Non-Party States: A Critique of the U.S. Position, 64 LAW \& CONTEMP. Probs. 67, 96-98 (Winter 2001); Ruth Wedgwood, The Irresolution of Rome, 64 LAW \& CONTEMP. PROBS. 193, 210-11 (Winter 2001).

38. For descriptions of the collapse of Yugoslavia, see generally DAVID OWEN, BALKAN ODYSSEY (1995); Laura Silber \& Allan Little, Yugoslavia: Death of A Nation (1996); Susan L. WOODWARD, BALKAN TRAGEDY: CHAOS AND DISSOLUTION AFTER THE COLD WAR (1995). 
gal process as a higher priority than a basic political resolution can adversely affect both the legal and political sides of the equation.

In short, much of the Yugoslav war crimes process seems to be about score settling rather than a more disinterested search for justice that will contribute to political reconciliation. If one side believes it is being unfairly treated, and holds this view strongly, then the "search for justice" will actually have harmed Bosnian national reconciliation by hardening pre-existing animosities. This is a case where it takes only one to tango. Outside observers might disagree with this assessment, but the outside observers do not live in Bosnia.

The experience of the Rwanda war crimes tribunal is even more discouraging. ${ }^{39}$ Widespread corruption and mismanagement in that tribunal's affairs have led many to hope that it expires quietly before doing more damage. At least as troubling, however, is the clear impression many have that score settling among Hutus and Tutsis - war by other means-is the principal focus of the Rwanda tribunal. Of course it is, and it is delusional to call this "justice" rather than "politics."

Although disappointed by the outcome in Rome, the Clinton Administration worked actively to bring the United States into the ICC. It continued to negotiate with signatories in the hope of obtaining sufficient amendments to allow the United States to sign on. In fact, whether the ICC survives and flourishes depends in large measure on the United States. For those opposed to the ICC, therefore, the correct policy now is to press Congress and subsequent administrations to ignore the ICC in official U.S. statements, and attempt to isolate it through U.S. diplomacy, in order to prevent it from acquiring any further legitimacy or resources. America's posture toward the ICC should be "Three Noes": no financial support, directly or indirectly; no cooperation; and no further negotiations with other governments to "improve" the ICC. Such a policy cannot entirely eliminate the risks posed by the ICC, but it can go a long way in that direction.

The United States should raise our objections to the ICC on every appropriate occasion, as part of our larger campaign to assert American interests against stifling, illegitimate, and unacceptable international agreements. The plain fact is that additional "fixes" to the ICC will not alter its multiple inherent defects, and we should not try to do so. The United States has many alternative foreign policy instruments to utilize that are fully consistent with our national interests, leaving the ICC to the obscurity it so richly deserves. Signatories of the Rome Statute have created an ICC to their liking, and they should live with it. We should not.

39. On Rwanda, see generally Fergal Keane, SEAson of Blood: A Rwandan Journey 